Historic, Archive Document

Do not assume content reflects current scientific knowledge, policies, or practices. 

62.41

Gladioli, Dahlias

Caladiums

\section{Tuberoses}

Cannas

Spireas

Etc.

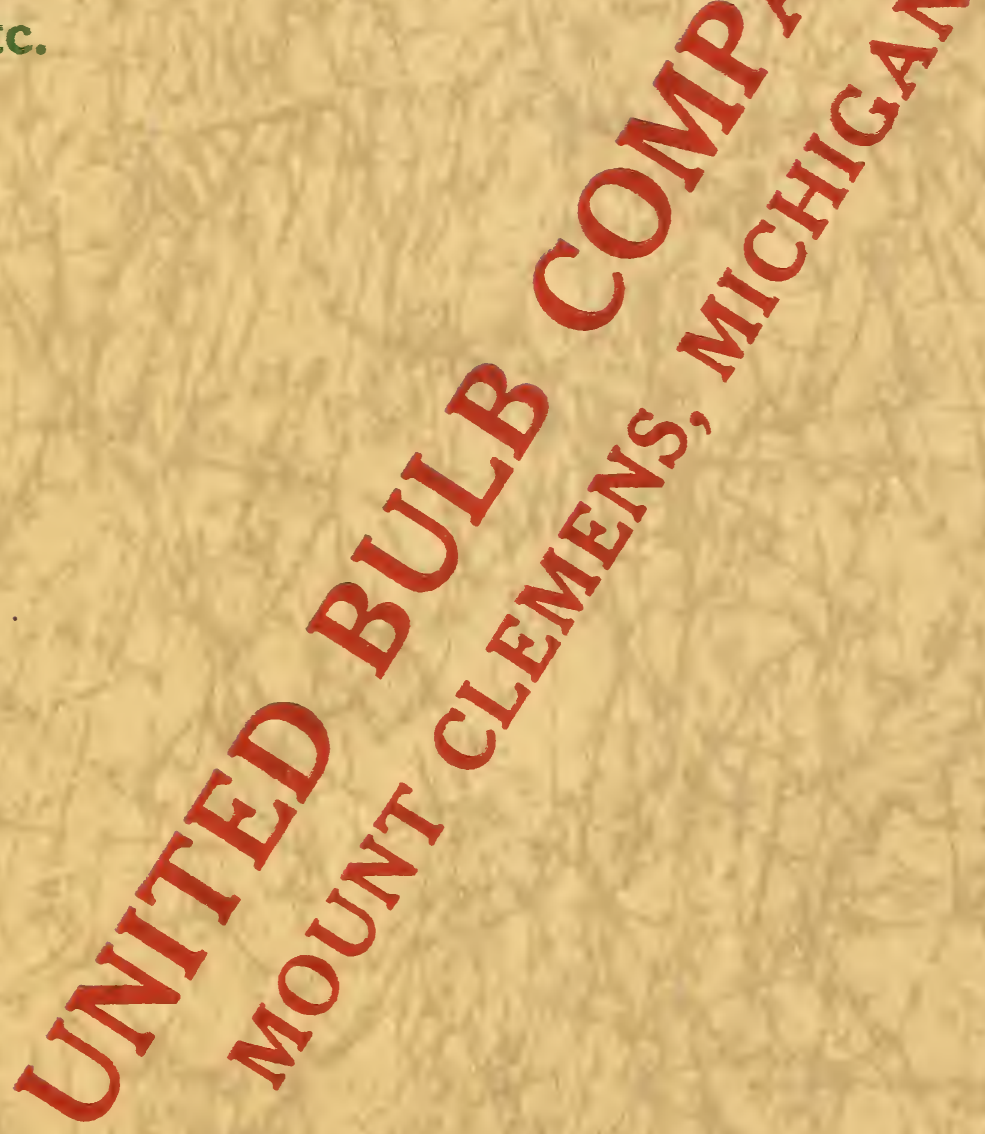

Fall, 1929

Spring, 1930

Wholesale Catalogue 


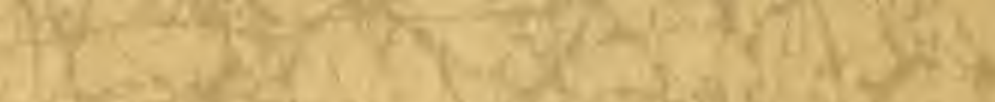

$9+\frac{\log }{6} \mathrm{~g}$

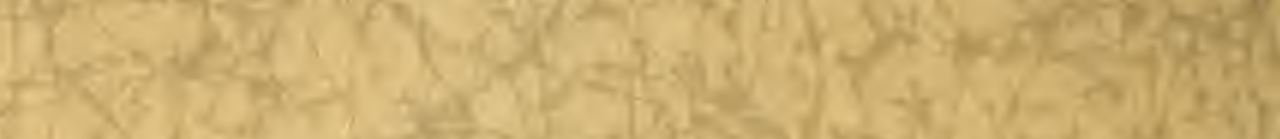

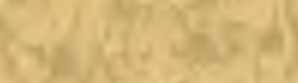
hyod

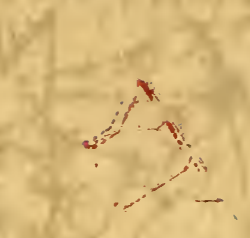

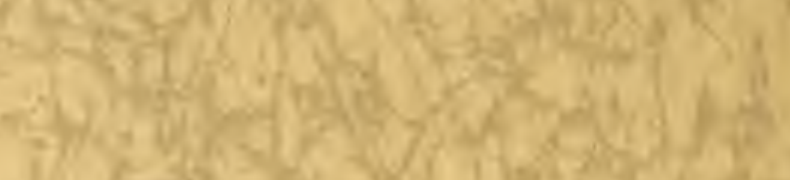

2.

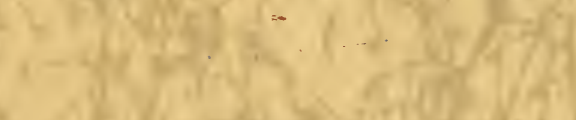

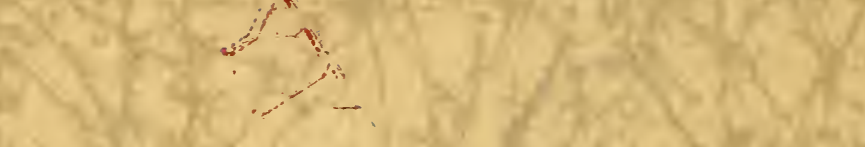

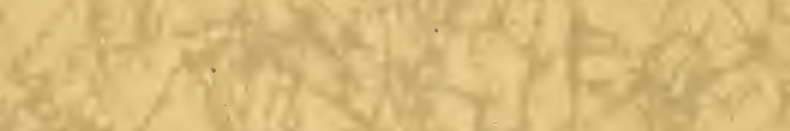

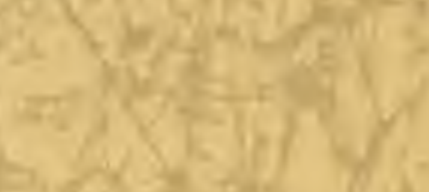

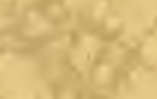

Q19\%

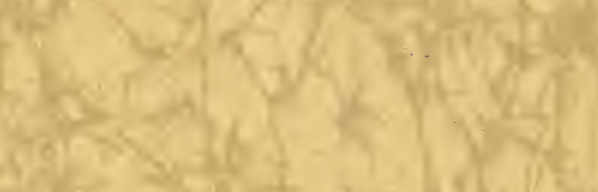

Q5.

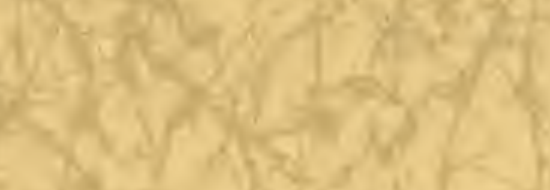

S.1.

.

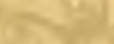

$x=y$

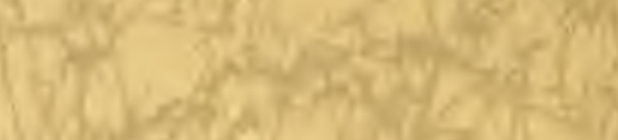

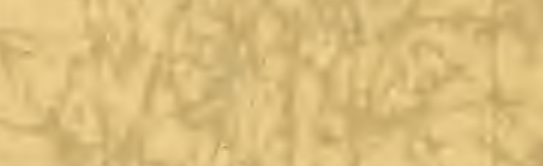

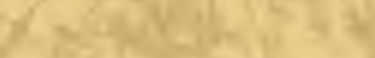

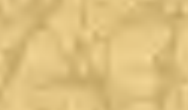

C. .10
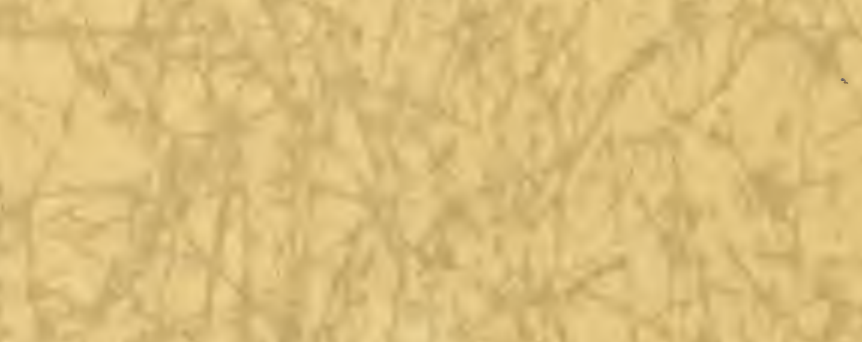
$\mid \begin{aligned} & 3 \\ & x^{2}\end{aligned}$ 


\section{TO OUR PATRONS:}

Our 1930 catalogue again contains several worthwhile new varieties and is mailed early, so as to allow our patrons to use any such descriptive matter as they might find useful.

This catalogue only contains Gladioli. Dahlias, Cannas, Spireas, Caladiums and Tuberoses, all of which are delivered in Winter and Spring; for Narcissi and Peonies, which are delivered in Summer and Fall, we will send out special price lists in MayJune.

Believing that this arrangement will meet with our patrons' approval, we are,

Yours sincerely,

UNITED BULB COMPANY. 


\section{TERMS OF SALE}

Prices in this catalogue are in anticipation of a normal crop and therefore subject to market fluctuations. After bulbs are harvested and during the selling and shipping season, we regularly mail our monthly stock lists with current prices. At such prices, orders are accepted subject to stock being unsold upon receipt of order.

All goods are sold f. o. b. Mt. Clemens, Mich., and travel at purchaser's risk, unless otherwise agreed. Cases and packing will be charged for at cost price.

Accounts are due 30 days after date of invoice; two per cent discount is allowed for payment within 10 days after date of inroice and three per cent is allowed for cash with order.

If at the time of shipment of any order or part thereof, purchaser has failed to settle his old accounts, or if we have reason to believe that his credit standing has suffered lately, we reserve the right to cancel all arrangements for transactions not yet executed.

We gire no warranty, expressed or implied, and will not be in any way responsible for the results of planting or forcing of any bulbs, roots or plants we send out; we guarantee all varieties to be true to the name and description.

Complaints and claims about quality cannot be entertained unless made within two days upon receipt of the goods.

All agreements, different from the above terms, have to be in writing; no verbal agreements will be considered.

By placing orders, buyer is considered to agree with these terms. 


\section{GLADIOLI}

\section{List of New Introductions}

AIDA, striking dark blue with large flowers, two small lilac red blotches in throat, very early.

First size, each $\$ 1.00$; medium size, each $\$ 0.65$; bulblets, per $100, \$ 10.00$.

APPLEBLOSSOM, very attractive appleblossom pink; tall, straight spike, many large flowers open at a time; a rare beauty.

First size per $100, \$ 35.00$; medium, $\$ 25.00$; bulblets per $1000, \$ 15.00$.

BERTY SNOW, light lavender orchid color, giant blooms, tall and vigorous. It is one of the very best in its color, by some considered better than Minuet.

First size, per 100, $\$ 75.00$; medium size, per 100, $\$ 50.00$; bulblets, per $1000, \$ 30.00$.

CATHARINE COLEMAN, an exceedingly choice variety of a rich coral La France pink. One of the aristocrats and considered by many as the world's choicest pink. Tall, straight stems, well placed flowers.

First size, per $100, \$ 25.00$; medium size, per $100, \$ 16.00$; bulblets, per $1000, \$ 10.00$.

CHARLES DICKENS, purple violet, similar to Anna Eberius, but taller spikes and more flowers on the stem. A very good grower and choice variety.

First size, per $100, \$ 25.00$; medium size, per $100, \$ 16.00$; buiblets, per $1000, \$ 10.00$.

COPPER BRONZE, deep salmon bronze Primuliness, overlaid with a coppery shade, tips of petals have a metallic color of deep bronze. One of the few and best copper colored Glads thus far introduced, unique and dazzling.

First size, per 100, $\$ 20.00$; medium size, per $100, \$ 12.00$; bulblets, per $1000, \$ 10.00$.

EMILE AUBURN, indescribable blend of rose and orange with a slaty gray overtone, scarlet and rose blotch on lower petals, a long spike of well placed flowers of most unusual coloring.

First size, per $100, \$ 35.00$; medium size, $\$ 20.00$; bulblets, per 1000 , $\$ 15.00$.

GERALDINE FARRAR, beautiful pale lavender blue with deep violet spot on lower petals. A beautiful variety, though not quite as good as Mrs. Van Konynenburg, which is a little darker in color.

First size, per $100, \$ 40.00$; medium size, per $100, \$ 25.00$; bulblets, per $1000, \$ 20.00$.

GLORIANA, tall spike with large flowers of the finest golden salmon, pure yellow throat. A very beautiful variety.

First size, per $100,25.00$; medium size, per $100, \$ 16.00$; bulblets, per 1000 , $\$ 8.00$; per quart, $\$ 30.00$.

GOLDEN DREAM, pure golden yellow, the spike and size of flower is like Golden Measure, though its color is betier and clearer yellow. This variety will become one of the leading yellow cutflowers.

First size, per $100, \$ 60.00$; medium size, per $100, \$ 40.00$; bulb!ets, per $1000 \$ 20.00$; per quart, $\$ 70.00$.

GOLDEN WONDER, purest golden yellow; very strong, tall spike with many flowers open at one time; a robust grower and one of the finest yellows ever introduced; large flowering Primuliness type.

First size each, $\$ 5.00$; medium size, $\$ 3.00$; bulblets per dozen, $\$ 5.00$, per $100, \$ 30.00$.

HEAVENLY BLUE, large clear delicate lavender blue of great refinement and elegance, truly a gorgeous color. Large flowers on long graceful spike.

First size, each $\$ 6.00$; medium size, each $\$ 4.00$; bulblets, per dozen, $\$ 5.00$. 


\section{GLADIOLI-Continued}

HERBSTZAUBER, beautiful warm salmon-copper color; very large flowers of exquisite form; tall; late flowering.

First size per $100, \$ 35.00$; medium, $\$ 25.00$; bulblets per $1000, \$ 15.00$.

H. KANZLEITER, very large dark red; at least as early as Halley; extra good grower and propagator.

First size per $100, \$ 10.00$; medium size, $\$ 7.50$; bulblets per $1000, \$ 5.00$.

JOERGS WHITE, pure snow white, the lower petal shades to creamy yellow in the throat. One of the largest flowers and almost as good as Mammoth White.

First size, per $100, \$ 25.00$; medium size, $\$ 16.00$; bulblets, per 1000 , $\$ 8.00$; per quart, $\$ 30.00$.

JOHN T. PIRIE, mahogany brown with yellow boarded brown throat, color most unusual and attractive.

First size, per $100, \$ 15.00$; medium size, $\$ 10.00$; bulblets, per $1000, \$ 5.00$.

KING OF THE BLUES, deep velvety purple, no markings whatsoever; it has the most beautiful deep purple color we know of, but is not easy to grow.

First size each, $\$ 1.00$; medium size each, $\$ 0.75$; bulblets per doz., $\$ 1.00$.

KIRCHHOFF'S VIOLET, deep rich velvety violet, large flowers, well placed on sall, straight spike, very attractive.

First size, per $100, \$ 30.00$; medium size, per $100, \$ 20.00$; bulblets, per $1000, \$ 15.00$.

KRIEMHILDE, lilac pink of good substance and noble form, large flowers on straight stalk.

First size, per $100, \$ 40.00$; medium size, per $100, \$ 25.00$; bulblets, per $1000, \$ 10.00$.

LILAC WONDER, a beautiful shade of pure light lavender; tall, straight spike; flowers well placed; one of the nicest shades we have ever seen; extra good multiplier.

First size per $100, \$ 30.00$; medium size, $\$ 20.00$; bulblets per $1000, \$ 10.00$.

LONGFELLOW, clear La France pink; tall, slender, wiry spike of large, wide open flowers; does not wilt or burn in the hottest weather.

First size per $100, \$ 20.00$; medium size per $100, \$ 12.50$; bulblets per $1000, \$ 8.00$.

MAGNOLIA, a new type of flower in gladioli. It resembles to perfection the wellknown flowers of the "Tulip Tree" or "Magnolia"; color, white; tall, straight stem.

First size each, $\$ 0.50$; medium size, $\$ 0.35$; bulblets per $100, \$ 5.00$.

MAMMOTH WHITE, the largest flower of any gladiolus we know of, measuring 7 inches in diameter; straight spikes, 5 feet tall; color pure paper-white. First size each, $\$ 3.50$; medium size each, $\$ 2.50$; bulblets per dozen, $\$ 3.00$.

MINUET, beautiful clear pure lavender, good size flowers of great elegance.

First size per $100, \$ 75.00$; medium size per $100, \$ 50.00$; bulblets per $1000, \$ 30.00$.

MRS. F. C. HORNBERGER, a beautiful pure white Gladiolus without markings. Nicely ruffled, wide open perfectly placed flowers of good texture. Many flowers open on strong, sturdy spike.

First size per $100, \$ 40.00$; medium size per 100 , $\$ 25.00$; bulblets per $1000, \$ 10.00$; quart, $\$ 30.00$. 


\section{GLADIOLI-Continued}

MRS. P. W. SISSON, clear cameo pink of large size, very sturdy and vigorous.

First size per $100, \$ 30.00$; medium size per $100, \$ 20.00$; bulblets per $1000, \$ 10.00$.

MRS. VAN KONYNENBURG, matchless aniline blue; beats far the color of any other blue variety; grows $\mathbf{5}$ feet tall; stems erect, flowers well placed on stem; even the very last top flower opens up in its true color; without doubt the best blue today.

First size per $100, \$ 125.00$; medium size per $100, \$ 80.00$; bulblets per $100, \$ 10.00$.

PFITZERS TRIUMPH, a super-gladiolus, one of the best ever introduced; color resembles the variety $\mathrm{Dr}$. Bennett, but the flowers are still larger and of twice the substance; also better shape and nicer form, measuring 6 inches in diameter; color bright orange-salmon with small velvet red mark in throat. It is absolutely irresistible. Imagine a five-foot tall spike, the last flower of which, either in water or out in the field, opens up in perfect shape, retains its full color, and is still as big as an America.

First size per $100, \$ 100.00$; medium size per $100, \$ 65.00$; bulblets per $100, \$ 8.00$.

PHAENOMEN, a beautiful gladiolus, the color a blending of salmon-pink and rich yellow; very good spike with perfectly placed flowers.

First size per $100, \$ 10.00$; medium size per $100, \$ 7.50$; bulblets per 1000 , $\$ 5.00$.

PRINCE OF ORANGE, orange salmon, unusual bright color; strong, tall flower spike; good grower and rapid propagator; excellent cutflower.

First size per $100, \$ 10.00$; medium size, $\$ 6.50$; bulblets per $1000, \$ 5.00$.

PUREST OF ALL, a splendid pure white variety of large size; excellent spike with well placed flowers; all that the name implies.

First size per $100, \$ 40.00$; medium size, $\$ 30.00$; bulblets per $1000, \$ 15.00$.

SANS PAREIL, apricot pink with white blotch. The well placed large flowers form a perfect spike. A beautiful French introduction.

First size per $100, \$ 20.00$; medium size per $100, \$ 12.50$; bulblets per $1000, \$ 8.00$.

THE ORCHID, a real new type. Long, narrow petals, slightly notched and ruffe Color is orchid over white, with rose lilac feathering in throat. The most orchid-like Gladiolus in the world.

First size, per 1000, $\$ 125.00$; medium size, per 1000, $\$ 75.00$; bulblets, per $1000, \$ 5.00$; quart, $\$ 20.00$.

VEILCHENBLAU, deep violet-blue, much larger flowers than Baron Hulot; however, not a very good propagator.

First size per $100, \$ 100.00$; medium size per $100, \$ 65.00$; bulblets per $100, \$ 10.00$.

YELLOW WONDER (Pfitzer), pure soft yellow, large flowers without any markings. First size each, $\$ 2.50$; medium size each, $\$ 2.00$; bulblets per dozen, $\$ 2.00$. 


\section{HINTS FOR FORCING GLADIOLI}

Buy large bulbs, $1 \frac{1}{2}$ inch up, and order early. Of most varieties, young, high crowned bulbs give the best results; they must have been dug early and stored away for about $31 / 2$ months in a well ventilated warehouse at the right temperature. Plant about the middle of January and put the bulbs 5-6 inches apart. Do not water them too much, just keep them moist; you can give them plenty of water when the buds are out. Temperature between 48 and 52, a little warmer when they are ready to bloom. The more light and sunshine, the better; if they are shaded too much, many will come blind. 


\section{LIST OF STANDARD VARIETIES}

Prices are quoted per 1000. 100 of a variety will be sold at the 1000 rate. Add $10 \%$ to all orders for less. Special prices on large quantities.

\begin{tabular}{|c|c|c|c|}
\hline & $1 \mathrm{st}$ & 2nd & $3 \mathrm{rd}$ \\
\hline & Size & Size & Size \\
\hline Per 1000 & $\begin{array}{l}11 / 2 \text {-in. } \\
\text { up }\end{array}$ & $\begin{array}{l}11 / 4-11 / 2 \\
\text { inch }\end{array}$ & $\begin{array}{l}1-11 / 4 \\
\text { inch }\end{array}$ \\
\hline
\end{tabular}

AFTERGLOW, one of the most beautiful scarlet colors

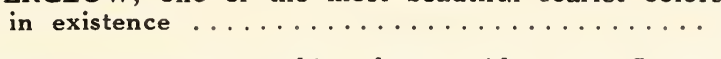

ALBANIA, pure snow white, large wide open flowers with beautiful round petals, extra............

AL SHIRA, large, very dark wine red with almost black

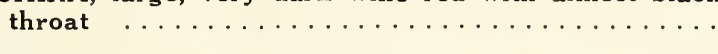

AMERICA, soft lavender pink, with lighter throat; good flower spike; very popular .............

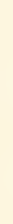

AMERICAN BEAUTY, brilliant American Beauty Rese color, creamy yellow throat; many large flowers open at a time on strong stem .............

ANNA EBERIUS, deep velvety purple with dark Bordeaux center; large flowers on strong siem.......

ANTHONY B. KUNDERD, delicate cream, overlaid blush pink, lower petals primrose yellow with pink edges; very strong, robust grower; heavily ruffled,

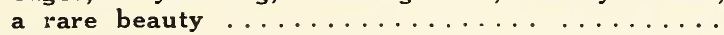

ARIZONA, deep rose pink with maroon markings on lower petals; tall, strong cutflower of great keeping qualities. A-1 florist variety and good forcer...

AUTUMN QUEEN, creamy yellow with large red blotch in throat; very late blooming; tall, strong spike...

A. W. HUNT, flame orange red; large, wide open flowers on strong, sturdy stem; not tall and therefore excellent for landscaping not tall and therefore ex-

BARON JOS. HULOT, deep indigo blue; flowers are not large, but there is nothing better in that color.....

$80.00 \quad 40.00$

$25.00 \quad 20.0 ?$

16.00

$55.00 \quad 45.00$

36.00

25.00

20.00

16.00

$25.00 \quad 20.00$

16.00

40.00

32.00

25.00

$45.00 \quad 36.00$

28.00

BENGAL TIGER, a peculiar dull red with dusky, bluishgray stripes; a very striking variety..........

BLUE JAY, bright blue with slight yellow reflex in throat, white spots on lower petals; tall, graceful

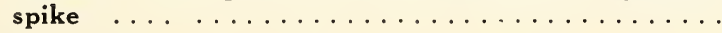

BREAK O' DAY, soft La France pink flushed with cream. Tips of petals are a shade deeper pink. There is a zone of light yellow on lower petals with delicate

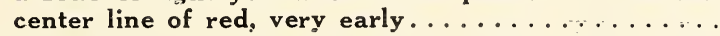

$45.00 \quad 36.00$

25.00

$80.00 \quad 65.00$

50.00

BYRON L. SMITH, delicate lavender, deepest at the edges of the petals and shading toward white in the cen. ter; gives the impression of an orchid. Well arranged on good stem

CAPTAIN BOYNTON, beautiful lavender with deeper blotch on lower petals; perfectly placed, large flow. ers on tall, strong stem; an excellent variety and early forcer 


\section{GLADIOLI-Continued}

$\begin{array}{cccc} & 1 \text { st } & \text { 2nd } & \text { 3rd } \\ \text { Per } 1000 & \text { Size } & \text { Size } & \text { Size } \\ 11 / 2-i 11 . & 1 / 4-11 / 2 & 1-11 / 4 \\ \text { inch } & \text { inch }\end{array}$

$35.00 \quad 28.00$

22.00

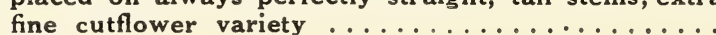

CATHARINA, grayish lavender, throat darker with mahogany red blotch; flowers well placed on long stem; very early forcer ...................

CHATEAU THIERRY, orange-cerise with yellow bordered red blotch on lower petals; tall spike with wide open, well formed flowers............

CHICAGO WHITE, early white, lower petals marked with lavender stripes; old standard variety........

CHRIS, deep maroon, shaded purple; strong straight

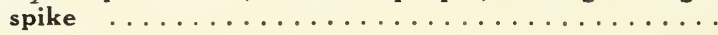

CONSPICUOUS, light blue with dark blue bordered yellow throat; gives the impression of a pansy.......

50.00

40.00

32.00

25.00

20.00

16.00

22.00

17.00

13.00

40.00

32.00

25.00

$35.00 \quad 28.00$

22.00

CRIMSON GLOW, glowing, velvety crimson, shaded deeper in the center; tall, strong grower, flowers well placed; considered the best in its color .......

CRINKLES, deep peach blossom pink; intensely ruffled petals; strong, vigorous plant.............

28.00

22.00

16.00

125.00

100.00

75.00

DIANA, brilliant crimson; wide open flowers on tall, strong stem; extra good cutflower variety........

35.00

28.00

22.00

DIENER'S WHITE, milk-white with a faint touch of blush in the throat, lower petals overlaid with a sheen of pale orchid; extra large flowers and vigorous

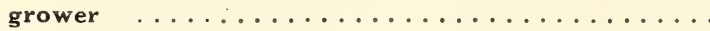

DISTINCTION, darls purplish maroon; very tall spike with well placed flowers $\ldots \ldots \ldots \ldots \ldots \ldots \ldots$.

DREAM, deep salmon red with large throat blotches of dark red; large, ruffled flowers and strong, sturdy

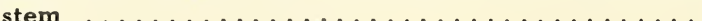

DR. F. E. BENNETT, peach red, overlaid with flame scarlet, throat speckled ruby and creamy white; very large flowers of great substance, many open at a time on strong stem; sturdy grower.........

DUCHESS OF YORK, beautiful purple blue; large open flowers well placed on erect, strong stems........

EARLY SUNRISE, deep orange salmon with yellowish blotch on lower petals; very early, excellent florist

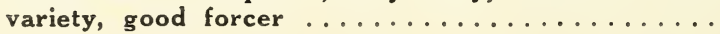

E. J. SHAYLOR, splendid deep rose pink; one of Kunderd's best ruffled varieties; good cutflower.......

ELF, lemon yellow when in bud, opens up pure white with pale yellow lower petal; large flowers and perfectly built spike; very good propagator and good cutflower variety $\ldots \ldots \ldots \ldots \ldots \ldots \ldots \ldots$
$50.00 \quad 40.00$

32.00

$50.00 \quad 40.00$

32.00

$60.00 \quad 48.00$

38.00

$130.00 \quad 80.00$

65.00

$50.00 \quad 40.00$

32.00

40.00

32.00

25.00

$25.00 \quad 20.00$

16.00

$40.00 \quad 32.00$

25.00 


\section{GLADIOLI-Continued}

Per 1000

ELIZABETH TABOR, delicate rose-pink with rich crimson blotch; tall, erect spike with several flowers open at one time; extremely early and therefore very valuable as a commercial cut flower variety.......

ELORA, creamy white, deeper shaded throat with carmine blotch; very early blooming............

EMPRESS OF INDIA, rich, dark purplish maroon, one of the darkest colored glads.............

ENERGIE, deep glowing scarlet, well placed flowers on long stem; very early, good forcer...........

EUROPA, splendid pure white; the large, well shaped flowers all open at a time, making it a gorgeous display of the purest white; absolutely the best white in existence, but very poor propagator..........

EVELYN KIRTLAND, very warm rose pink, deeper at the edges of the petals sha.ing towards shell pink in the center, brilliant scarlet blotches on the lower petals; strong stem, making it one of the most desirable varieties for cutting $\ldots \ldots \ldots \ldots \ldots \ldots \ldots$

FAIR COLUMBIAN, pure lilac, shaded deeper in the center; tall vigorous grower; extra for cutting pur-

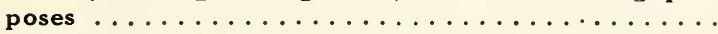

FAY LANPHIER, large flowers of coral lustre with cerise

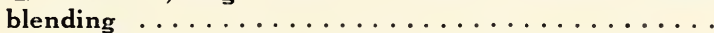

FERN KYLE, creamy white; large, heavily ruffled flowers, many open at a time on long, strong stem; a wonderful, refined variety $\ldots \ldots \ldots \ldots \ldots \ldots \ldots$

FLAMING SWORD, brilliani red, overlaid with orange; as many as 10 flowers open at a time, well placed on tall, straight stem; very early ...........

FLORA, pure deep yellow; well shaped blooms on tall strong stems; one of the best, but hard to grow....

GERTRUDE ERREY, shell pink shading to almost whitz iri center, spot of deeper color in throat; tall graceful

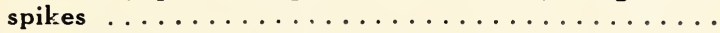

GIANT NYMi-H, light rose pink, with creamy yellow throat; very large, wide open flowers, well arranged on long stems; grows 6 feet tall. ...........

GLENDALE, velvety dark American Eeauiy red; flowers well placed on long, strong stem; great keeper and therefore an excellent cutflower variety.........

GLORY OF KENNEMERLAND, deep rose with creamy yellow throat blotch; very large, wide open flowers on strong, stiff stem; very striking..........

GOLD, clear golden yellow, self-color; large; by many considered the purest yellow...............

$\begin{array}{ccc}1 \text { st } & \text { 2nd } & \text { 3rd } \\ \text { Size } & \text { Size } & \text { Size } \\ 1 / 2 \text {-in. } & 1 / 4-11 / 2 & 1-11 / 4 \\ \text { up } & \text { inch } & \text { inch }\end{array}$

$40.00 \quad 32.00$

25.00

$25.00 \quad 20.00$

16.00

$50.00 \quad 40.00$

32.00

$40.00 \quad 32.00$

25.00

$80.00 \quad 65.00$

$\mathbf{5 5 . 0 0}$

25.00

20.00

16.00

$50.00 \quad 40.00$

32.00

$50.00 \quad 40.00$

32.00

$60.00 \quad 50.00$

40.00

$35.00 \quad 28.00$

22.00

$45.00 \quad 36.00$

28.00

$70.00 \quad 55.00$

45.00

$35.00 \quad 28.00$

22.00

40.00

32.00

25.00

35.00

28.00

22.00

$45.00 \quad 36.00$

28.00 


\section{GLADIOLI-Continued}

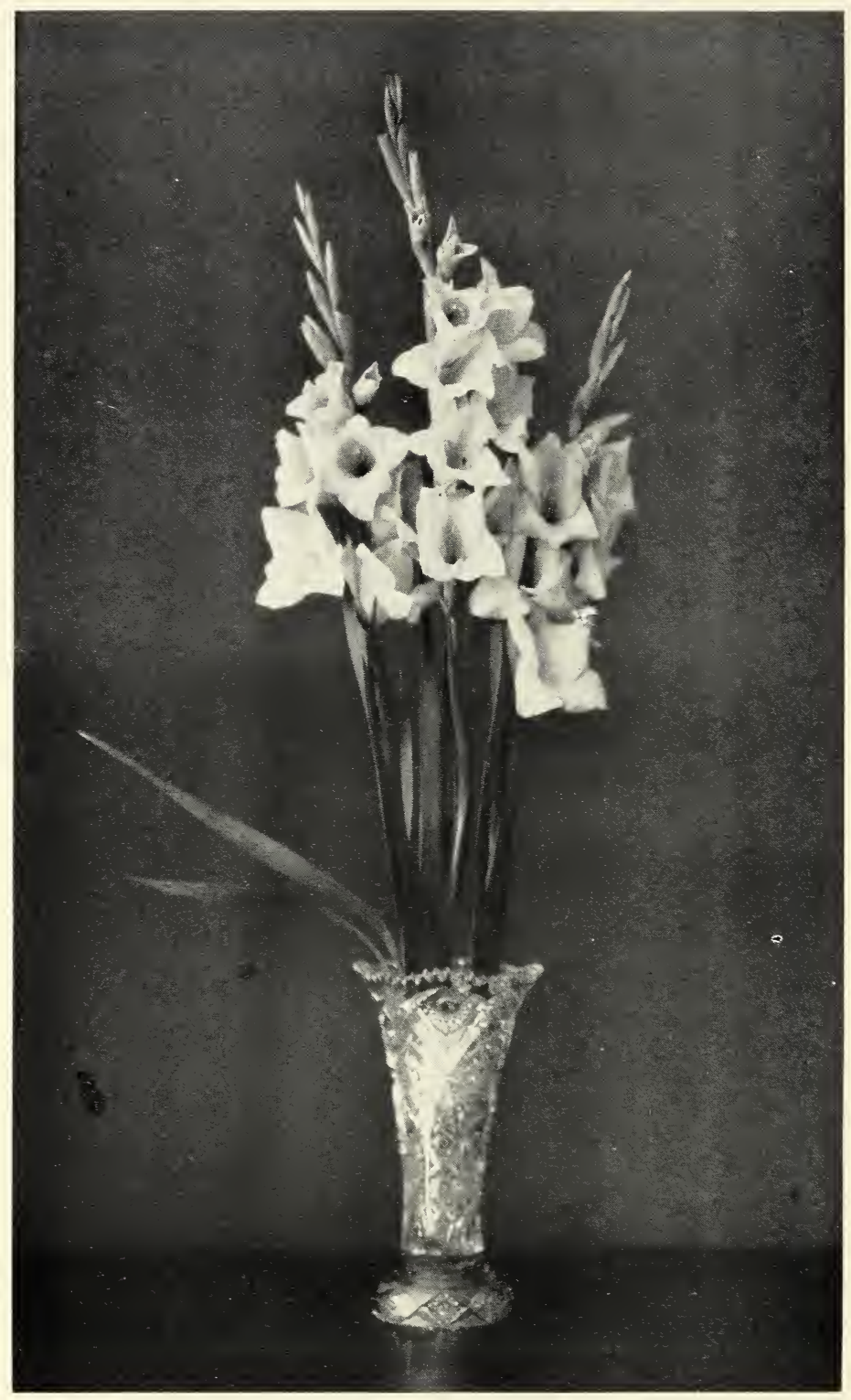

Carmen Sylvia 


\section{GLADIOLI-Continued}

$\begin{array}{cccc} & \text { 1st } & \text { 2nd } & \text { 3rd } \\ \text { Per 1000 } & \text { Size } & \text { Size } & \text { Size } \\ & 1 / 2-\text {-in. } & 1 \frac{1}{4}-1 \frac{1}{2} 2 & 1-11 / 4 \\ & \text { up } & \text { inch } & \text { inch }\end{array}$

GOLDEN MEASURE, pure golden yellow; very large flowers of good substance; robust grower and considered the best yellow on the market; a superglad. .

$55.00 \quad 44.00$

35.00

GOLDEN WEST, rich orange red with golden reflex, lower petals tipped yellow; graceful, wiry stem....

GOLIATH, deep purplish maroon; very large flowers on tall, strong stem; the best dark on the market.....

$35.00 \quad 28.00$

22.00

$50.00 \quad 40.00$

32.00

GRETCHEN ZANG, beautiful soft pink shading to geranium pink at the edges of the petals, bright scarlet blotches on lower petals, a very pleasing combination; tall, graceful spike; sunburns, therefore to be planted late................

HALLEY, salmon pink with creamy yellow blotch on lower petals; very early and great favorite as a commercial cutflower ................

HELGA, salmon-rose, shading towards creamy-blush in the throat; tall, graceful spikes; excellent, early forcer, blooming over $150 \% \ldots \ldots \ldots \ldots \ldots$.

HERADA, clear mauve, shaded deeper in the center; large flowers, many open at a time, very attractive. .

IDA VAN, brilliant deep salmon red; good, strong

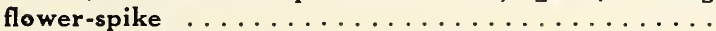

J. A. CARBONE, iridescent orange salmon, shaded darker towards the edges, center yellow; large flowers well placed on long stem; extra fine............

JACK LONDON, light salmon with vermilion stripes, canary-yellow throat; perfectly placed flowers on strong stems; a robust grower.............

$25.00 \quad 20.00$

16.00

$22.00 \quad 17.00$

40.00

32.00

25.00

$25.00 \quad 20.00$

16.00

$25.00 \quad 20.00$

16.00

$65.00 \quad 50.00$

40.00

$40.00 \quad 32.00$

25.00

JACOBA VAN BEYEREN, pure deep violet, self color; flowers well placed on tall, erect stem; highly recommendable $\ldots \ldots \ldots \ldots \ldots \ldots \ldots \ldots \ldots$.

JOE COLEMAN, bright red, carmine blotch; very attractive, ruffled flowers; many open at a time; strong grower and good propagator. .

KARL VOLKERT, light salmon red; flowers well placed on tall, straight spike; one of the earliest in bloom

KUNDERDI GLORY, creamy apricot, tinted light pink, suffused with red on lower petals; the parent of all ruffled Kunderd varieties ..................

LE MARECHAL FOCH, clear light pink, a shade brighter than America; very large, wide open flowers on strong, stiff stem; very early and useful cutflower..

LIEBESFEUER (Lovesfire), dazzling scarlet; perfectly placed flowers on strong stem; the best scarlet today

$50.00 \quad 40.00$

$30.00 \quad 24.00$

18.00

$60.00 \quad 50.00$

40.00

$45.00 \quad 36.00$

28.00

22.00

17.00

13.00

$50.00 \quad 40.00$

32.00

LILY LEHMAN, ivory white; large, lily shaped flowers; unique in appearance, resembling a lily......... 


\section{GLADIOLI-Continued}

LILY WHITE, creamy white shading to cream in the center; very early; good cutflower.............

$\begin{array}{ccc}\begin{array}{c}\text { 1st } \\ \text { Size } \\ 1 \mathrm{~L} / \mathrm{2} \text {-in. } \\ \text { up }\end{array} & \begin{array}{c}\text { 2nd } \\ \text { Size } \\ 11 / 4-1 / 2 \\ \text { inch }\end{array} & \begin{array}{c}\text { 3rd } \\ \text { Size } \\ 1-11 / 4 \\ \text { inch }\end{array} \\ \mathbf{2 5 . 0 0} & \mathbf{2 0 . 0 0} & \mathbf{1 6 . 0 0}\end{array}$

L'IMMACULEE, pure white; tall slender stems with many flowers open at a time; very desirable cutflower variety; early, dependable forcer.............

LOS ANGELES, beautiful shrimp pink with glowing orange carmine blotch in throat, tall and graceful stems. One of the best forcing varieties for florists, most bulbs blooming with two spikes..........

40.00

32.00

25.00

LOUISE, orchid lavender with deeper blotch in throat, a refined color combination; wide open flowers on

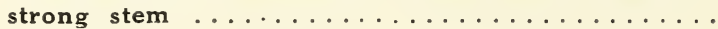

LOVELINESS, cream suffused with apricot and light pink; very large, perfectly shaped flowers on long, strong stem; a variety of great merit..............

LUCIE, clear light yellow; large flowers well placed on tall, erect stems; very early and excellent forcer...

LUSTRE, orange vermilion, suffused crimson; large, wide open flowers; many open at a time, making the whole a bouquet itself . .............

MAINE, opens up a lemon yellow, turning into pure white when in full bloom; giant stems with per. fectly placed, wide open flowers; a beauty......

MAJESTIC, deep orange pink shading to flush pink in throat, creamy white blotch on lower petals, a brilliant color combination; very large, wide open flowers, early blooming ...............

$50.00 \quad 40.00$

$50.00 \quad 40.00$

$50.00 \quad 40.00$

$60.00 \quad 50.00$

40.00

$50.00 \quad 40.00$

32.00

MARIE KUNDERD, purest white with almost invisible pink lines in center of lower petals; finely ruffled and very early $\ldots \ldots \ldots \ldots \ldots \ldots \ldots \ldots$

$50.00 \quad 40.00$

32.00

MARSHALL FOCH, finest warm salmon pink, with small red blotch in throat; giant flowers and stem, slightly ruffled $\ldots \ldots \ldots \ldots \ldots \ldots \ldots \ldots \ldots \ldots \ldots \ldots \ldots \ldots$

$50.00 \quad 40.00$

32.00

MARY FENNELL, deep grayish lavender, lighter towards center, with soft primrose yellow throat; medium sized stem, making it a good garden variety......

MARY PICKFCRD, lovely creamy white with soft sulphur yellow throat; stem also creamy instead of green, giving the whole a delicate, unique appear-

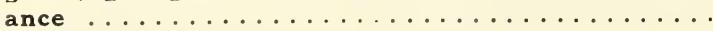

MEILUST, fine pink with deeper blotch, very early;

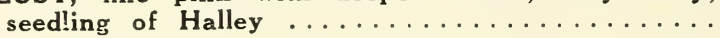

MISS HELEN FRANKLIN, white with purple throat blotches; ruffled; very prolific . ...........

MISS MADISON, purest deep pink, selfcolor; very large, wide open flowers, many open at a time; strong, long stems; extra $\ldots \ldots \ldots \ldots \ldots \ldots \ldots \ldots$ 


\section{GLADIOLI-Continued}

$$
\begin{array}{cccc} 
& 1 \text { st } & \text { 2nd } & \text { 3rd } \\
\text { Per 1000 } & \text { Size } & \text { Size } & \text { Size } \\
1 \frac{1}{2}-i n & 11 / 4-11 / 2 & 1-11 / 4 \\
\text { up } & \text { inch } & \text { inch }
\end{array}
$$

MONA LISA, pale lavender pink, pure selfcolor; many ruffled flowers open at a time; a splendid variety..

30.00

24.00

18.00

MR. MARK, light blue with darker blotch in throat; medium large flowers on strong stem; one of the best blues ....................6 60.00

50.00 40.00

MR. W. H. PHIPPS, La France pink, overlaid with salmon rose, lighter towards the center, lower petals faintly striped and speckled with ruby; enormous flowers, as many as 20 open at a time and per. fectly placed on gigantic stem; a real super glad. .

MR. TREUB, finest appleblossom pink; very tall, graceful spike with many flowers open at a time; good cutflower variety

MRS. DR. NORTON, silvery white base tinged with pink, deepening towards the edges of the petals, creamy blotches in throat on lower petals; tall, vigorous grower, splendid cutflower ..............

MRS. FRANCIS KING, flame red, shaded salmon towards throat; very tall, strong spike; an old favorite florist variety $\ldots \ldots \ldots \ldots \ldots \ldots \ldots \ldots \ldots \ldots \ldots \ldots$

MRS. FRANK PENDLETON, deep rose pink shading to pale pink in throat, large, bright crimson blotches on lower petals, giving it a striking appearance; tall, vigorous grower; extra cutflower and forcer..

MRS. FRED C. PETERS, fine lilac pink with purp!ish blotch in throat; many large flowers open at a time on long, erect stem; very vigorous grower, extra. .

$22.00 \quad 17.00$

25.00

20.00

16.00

40.00

25.00

MRS. GEORGE W. MOULTON, violet red, selfcolor; a giant in flowers and stem; many flowers open at a

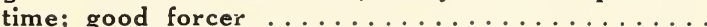

MRS. H. E. BOTHIN, geranium pink tinted salmon, flaming scarlet center, a very striking co'or combination; well placed, heavily ruffled flowers on strong stem; a leader.

MRS. LEON DOUGLAS, begonia rose striped with flame scarlet, lower petal pale lemon, speckled ruby; tremendously large flowers, many open at a time; very tall, strong stem with several side shoots, the whole forming a gigantic bouquet; considered one of

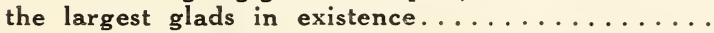

MRS. RICHARD LOHRMAN, creamy shell pink, lower petal pale yellow; very large, heavily ruffled flowers on long, sturdy stems; a decorative variety of indescribable beauty $\ldots \ldots \ldots \ldots \ldots \ldots \ldots \ldots$

MRS. WATT, wine red, the shade of the American Beauty rose; many flowers open on medium long stem, making it very adap'able for the garden....
$35.00 \quad 28.00$

22.00

$60.00 \cdot 50.00 \quad 40.00$

$80.00 \quad 65.00 \quad 50.00$

$30.00 \quad 24.00 \quad 18.00$ 


\section{GLADIOLI_Continued}

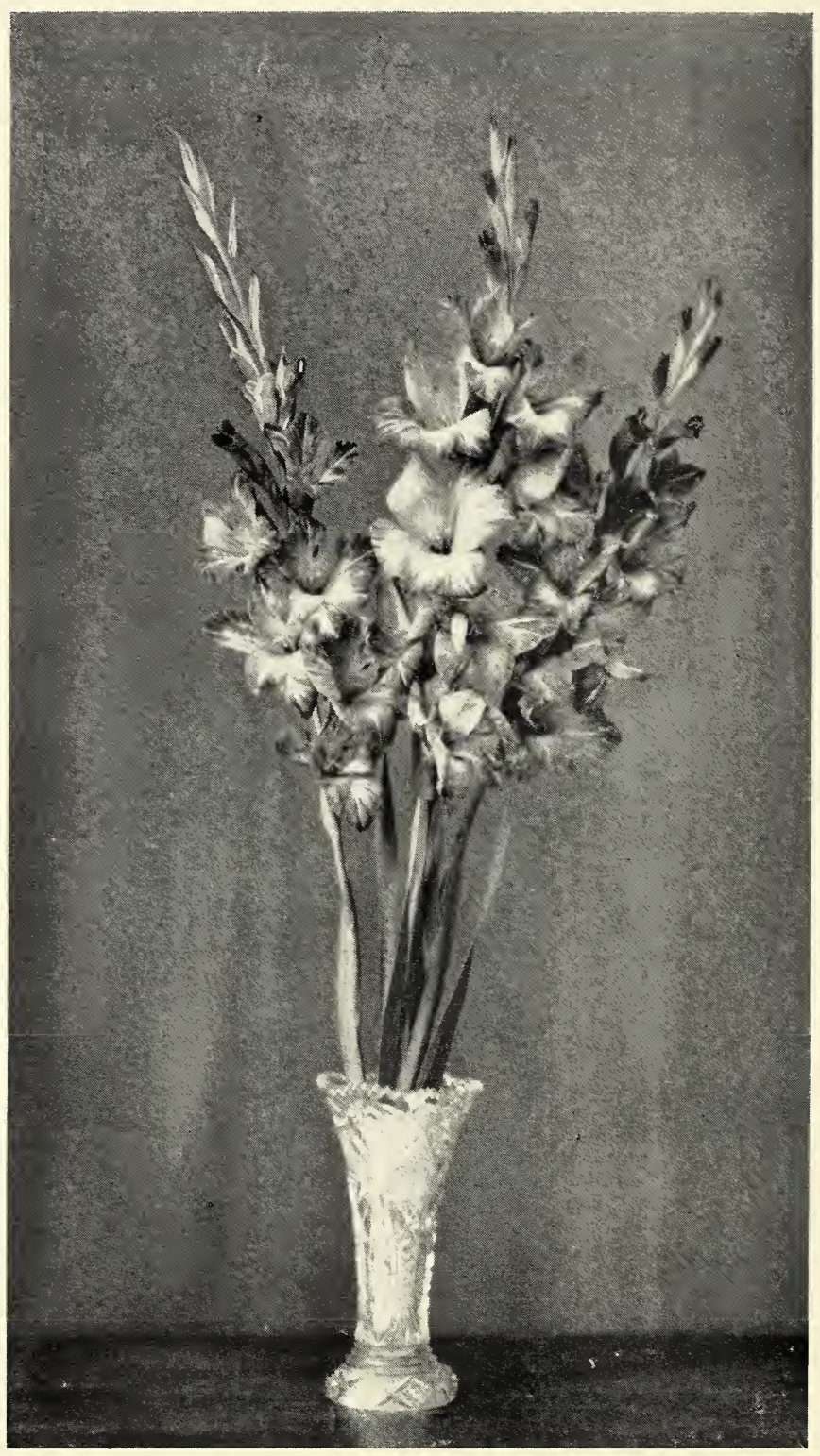

Early Sunrise 


\section{GLADIOLI-Continued}

$\begin{array}{cccc} & \text { 1st } & \text { 2nd } & \text { 3rd } \\ \text { Per } 1000 & \text { Size } & \text { Size } & \text { Size } \\ & 1 / 2-\text { in } & 1 \frac{1 / 4-11 / 2}{1-1} & 1 / 4 \\ \text { up } & \text { inch } & \text { inch }\end{array}$

MRS. WM. E. CLARK, rich salmon-pink with bright crimson blotch; flowers well placed on perfect stem;

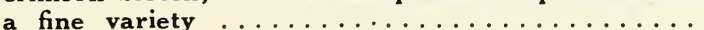

$75.00 \quad 60.00$

50.00

MURIEL, beautiful pure lilac blue with deeper blotch in throat on lower petals; many perfectly placed flowers open at a time on tall, erect stem; a rare

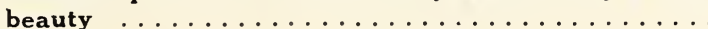

$\mathbf{5 5 . 0 0}$

45.00

35.00

MYRTLE, clear, delicate rose pink; fine, straight spike; a favorite cutflower and sure to please wherever shown good forcer and sure to please wherever

NEBRASKA, aster purple, sulphur yellow blotch on lower petals, tall strong spikes, well arranged flowers....

NIAGARA, primrose yellow, splashed and striped with bright pink; large flowers on good, strong spike; an

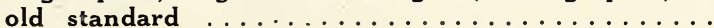

1910 ROSE, pure deep rose pink with white center lines on lower petals; strong, vigorous grower and very early, good cutflower ................

NORA, grayish lavender with darker spot on lower petals; well placed flowers on long stem........

ODIN, deep salmon pink with intense carmine blotch on lower petals, giving it a very warm color combination; large flowers on strong stem, very eariy, splendid cutflower and goor forcer............

$40.00 \quad 32.00$

25.00

$40.00 \quad 32.00$

25.00

30.00

18.00

22.00

40.00

25.00

30.00

24.00

18.00

ORANGE GLORY, deep orange with carmine blotched throat, creamy white stripes on lower petals; very vigorous, husky plant; broad foliage and heavily ruffled flowers on strong stem; extra for landscape

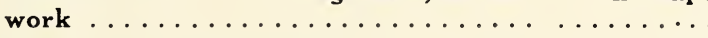

$40.00 \quad 32.00$

25.00

PANAMA, rose pink, selfcolor; very large, wide open flowers on stiff stems, many open at a time.....

$25.00 \quad 20.00$

16.00

PEACE, pure white with lilac feathering on lower petals; large flowers on long, strong stem, many open at a time; great variety for late blooming..........

PEACH ROSE, deep rose pink with rose-red blotches in throat; a wonderful variety ..............

PELLA, rose pink; medium size flower and good stem; very similar to E. J. Shaylor, but earlier; good cutflower variety ...................

PERSIA, deep mahogany red, almost black........

$40.00 \quad 32.00$

25.00

25.00

20.00

16.00

$45.00 \quad 36.00$

28.00

PINK PERFECTION, very warin pink, selfcolor; perfectly placed flowers on long, wiry stem, which has a habit of curving, making it excellent for basketwork

$50.00 \quad 40.00$

PINK WONDER, LaFrance pink shading to pale pink in the throat with yellow reflex at the base of the lower petals; immensely large............... 


\section{GLADIOLI-Continued}

$\begin{array}{cccc} & 1 \text { st } & \text { 2nd } & \text { 3rd } \\ \text { Per 1000 } & \text { Size } & \text { Size } & \text { Size } \\ 1 / 2-\text { in. } & 11 / 4-11 / 2 & 1-11 / 4 \\ \text { upch } & \text { inch }\end{array}$

PRESIDENT HARDING, large wine red flowers, shaded lighter toward center. Throat speckled deep maroon red, two small yellow stripes on lower petals. As many as 20 flowers on the spike. Very strong,

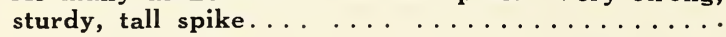

PRIDE OF GOSHEN, creamy pink; large, ruffled flowers on long stem; very vigorous plant; may be called "Improved Kunderdi Glory" ...............

PRIDE OF HILLEGOM, deep rich scarlet with lighter throat, cream lines on center of lower petals; tall, graceful stems with many flowers open at a time..

PRIDE OF LANCASTER, brilliant orange salmon with scarlet throat; beautifully ruffled flowers on tall,

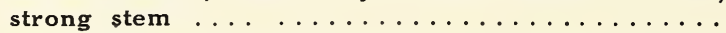

PRINCE OF WALES, delicate salmon pink, lighter toward the center; well shaped flowers on long stems; the earliest on the market; extra good forcer........

PRINCEPINE, brilliant carmine red with large white throat blotches; medium sized flowers and stem, well adapted for garden planting.............

PRINCEPS, brilliant scarlet with white blotch at the base of lower petals; immense amaryllis-like flowers; sturdy plant with heavy foliage..........

PROSERPINE, cerise pink; long, wiry stems which generally come curved, making it very useful for basket-

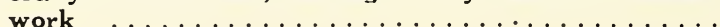

PURPLE GLORY, deepest velvety maroon with almost black blotches; large, ruffled flowers on very tall, sturdy stems; a real giant in all respects........

RAJAH, dark red, without any markings; many large flowers open at one time, forming a bouquet by itself; won several prizes as the best dark red......

RED CANNA, deep crimson; large flowers on very tall, wiry stems; very suitable for cutting. ..........

REV. EWBANK, beautiful porcelain blue with deeper blotch on lower petals; good, strong spike; early...

REX, brilliant scarlet; tremendously big flowers on enormous stems; one of the largest, tallest glads in existence $\ldots \ldots \ldots \ldots \ldots \ldots \ldots \ldots \ldots \ldots . \ldots \ldots$

RICHARD DIENER, geranium-pink with creamy yellow center, flaked carmine; immense blossoms on tall, stately spike; ruffled $\ldots \ldots \ldots \ldots \ldots \ldots \ldots \ldots$

ROMANCE, orange salmon rose, red and yellow throat, a bluish border surrounding each petal; very odd. .

$25.00 \quad 20.00 \quad 16.00$

$25.00 \quad 20.00 \quad 16.00$

$\begin{array}{lll}45.00 & 36.00 & 28.00\end{array}$

$\begin{array}{lll}35.00 & 28.00 & 22.00\end{array}$

$55.00 \quad 45.00 \quad 36.00$

$\mathbf{8 5 . 0 0} \quad \mathbf{7 0 . 0 0} \quad \mathbf{5 5 . 0 0}$

$30.00 \quad 24.00 \quad 18.00$

$80.00 \quad 65.00 \quad 50.00$

$60.00 \quad 50.00 \quad 40.00$

$30.00 \quad 24.00 \quad 18.00$

ROSA LINDT, deep cerise with white mark on lower petals; enormous flowers $\ldots \ldots \ldots \ldots \ldots \ldots \ldots$ 


\section{GLADIOLI-Continued}

$\begin{array}{cccc} & \text { lst } & \text { 2nd } & \text { 3rd } \\ \text { Per } 1000 & \text { Size } & \text { Size } & \text { Size } \\ 11 / 2-i n & 11 / 4-11 / 2 & 1-11 / 4 \\ \text { up } & \text { inch } & \text { inch }\end{array}$

ROSE ASH, old rose overlaid and blended with pink, blue and red, giving the color of ashes of roses, hence its name; large flowers on tall, strong spikes:

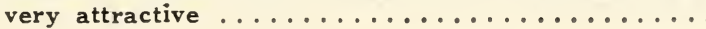

ROSE GLORY, purest rose pink with deeper throat; splendidly ruffled flowers on good spike........

$30.00 \quad 24.00 \quad 18.00$

ROSE PEARL, flesh pink with a pearl-like luster; sport of the Halley and Wilbrink, but without their yel. low markings on the lower petals; very early cut-

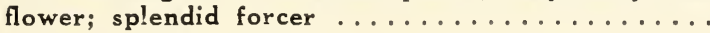

16.00

13.00

ROSE PRECOSE, beautiful salmon rose, slightly ruffled; many well placed flowers open at a time on long, straight stems; may be called "the straight Pink Perfection" ......................

SCARLANO, bright orange scarlet, with blood red throat; finely ruffled; extra good cutflower variety.

SCARLET PRINCEFS, fläming scarlet; large, massive flowers, many open at a time, making a gorgeous

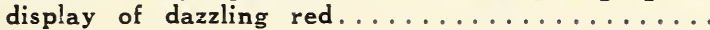

30.00

SCARLET WONDER, purest deep scarlet; mammoth flowers, many open at a time on tall, stiff stems;

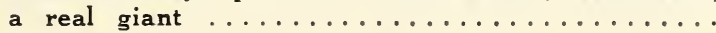

SCHWABEN, light yellow with little red stripes on lower petals; strong grower with large flowers and sturdy stem; an old favorite with florists..............

SHEILA, light salmon; large flowers on tall, erect stems;

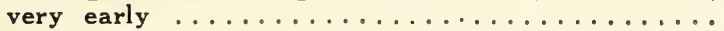

SIDNEY PLUMMER, soft yellow, suffused delicate pink, throa: slightly marked amaranth-purple; well placed, large flowers on tall, strong stem, many

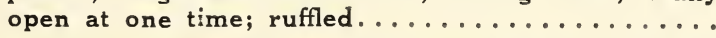

SUNNYMEDE, beautiful shade of orange-yellow, with red blotch; tall spike with many flowers open at one

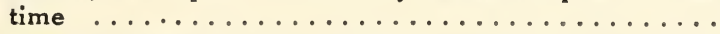

SWEET LAVENDER, light lavender with purple throat; one of the earliest in bloom and very attractive....

TARO, deep American Beauty Rose color; large flowers on strong spike; a real beauty...............

THOMAS EDISON, salmon orange; large, wide open flowers on strong stem; very early...........

TRUDEL GROTZ, glowing salmon pink with small red blotch in throat, giving the whole a warm, striking appearance; enormous flowers on strong, tall stem; very good grower and propagator............

TWILIGHT, creamy buff, edges of petals flaked pink, throat primrose yellow and pink: splendid ruffled variety 


\section{GLADIOLI-Continued}

\begin{tabular}{|c|c|c|}
\hline & $1 \mathrm{st}$ & 2nd \\
\hline Per 1000 & Size & Size \\
\hline er 1000 & $\begin{array}{l}172-111 . \\
\text { up }\end{array}$ & $\begin{array}{l}1 / 4-11 / 2 \\
\text { inch }\end{array}$ \\
\hline
\end{tabular}

TYCKO ZANG, clear salmon pink with white throat, faintly dotted cerise, immense flowers on perfect straight stems $\ldots \ldots \ldots \ldots \ldots \ldots \ldots \ldots \ldots \ldots$

TYRIAN BEAUTY, pure Tyrian rose, upper petals a shade lighter; large flowers, well placed on tall, straight stem; robust grower; very attractive.....

VENUS, creamy white overlaid with flush pink, yellow reflex on lower petals, the whole a very pleasing combination of delicate colors; it is the latest sport from Halley; has all its parent's good qualities: early, splendid cutflower and good forcer.......

VIOLA, bluish white with blue spot on lower petals; strong, erect stem; a very attractive variety......

VIRGINIA, flaming scarlet; large, massive flowers, many open at a time, making a gorgeous display of dazzling red; good forcer .................

WAR, deep blood red, shaded dark crimson; many flowers open on tall, straight stem; very late blooming.

WHITE GIANT, pure white; very large flowers, many open at a time on long, strong stem; petals are pointed, giving it a lily-like appearance........

WHITE GLORY, pure white with Iris-blue throat; heav. ily ruffled flowers on strong, stiff stem; sturdy

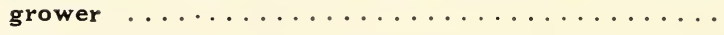

WHITE WONDER, pure white with faint lavender pink tints; large, wide open blooms well placed on long

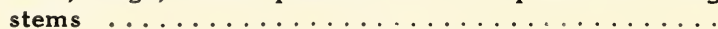

WILBRINK, flesh pink with yellowish blotch on lower petals; large, well placed flowers on tall, strong stems; the first pink to bloom, together with $\mathrm{Hal}$ ley, of which it is a sport; extra good cutflower and forcer .....................

WILLY WIGMAN, creamy white, flushed soft pink with large crimson blotch on lower petals; a very pleasing color combination; tall, erect stems, good forcer

WM. G. BADGER, coral pink, creamy throat, speckled ruby; a real giant in size of flowers and stem; many

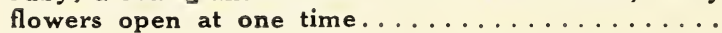

YELLOW HAMMER, pure primrose yellow with slight red mark in throat; flowers perfectly arranged on tall, graceful stem; very early, good cutflower and

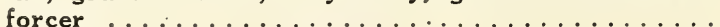

YOUELL'S FAVORITE, lavender pink; ruffled flowers; sturdy plant, both flowerspike and foliage....... 


\begin{tabular}{|c|c|c|c|}
\hline Per 1000 & $\begin{array}{c}1 \mathrm{st} \\
\text { Size } \\
11 / 2-i n . \\
\text { up }\end{array}$ & $\begin{array}{c}\text { 2nd } \\
\text { Size } \\
11 / 4-11 / 2 \\
\text { inch }\end{array}$ & $\begin{array}{c}3 r d \\
\text { Size } \\
1-11 / 4 \\
\text { inch }\end{array}$ \\
\hline & 20.00 & 16.00 & 12.00 \\
\hline & 25.00 & 20.00 & 16.00 \\
\hline & 25.00 & 20.00 & 16.00 \\
\hline$\ldots$ & 20.00 & 16.00 & 12.00 \\
\hline & 30.00 & 24.00 & 18.00 \\
\hline & 30.00 & 24.00 & 18.00 \\
\hline
\end{tabular}

\section{PRIMULINES HYBRIDS}

ALICE TIPLADY, bright saffron-orange; large, open flowers on strong, stiff stem; excellent cutflower

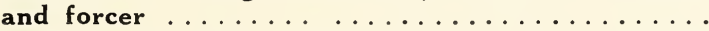

ALTAIR, saffron-salmon; very tall grower and one of the earliest to bloom; frequently produces two flower

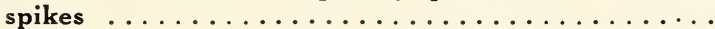

ARLON, bright orange-salmon with reddish throat; tall, slender spikes; very prolific bloomer..........

BUTTERBOY, clearest buttercup yellow; large flowers on tall, strong stem; very vigorous plant.........

$25.00 \quad 20.00$

15.00

$40.00 \quad 32.00$

25.00

CARARA, creamy white, long wiry stem ........ $\mathbf{8 0 . 0 0}$

65.00

50.00

DOROTHY WHEELER, pure delicate rose pink, flowers well placed on slender, graceful stem.........

$30.00 \quad 24.00$

18.00

GOLDEN GATE, light yellow with very faint red lines in throat; ruffled showy flowers on tall stem......

$25.00 \quad 20.00$

16.00

JEWELL, light salmon pink with beautiful golden yellow throat; flowers large and wide open on long, slender stems; a most attractive variety; early..........

$30.00 \quad 24.00$

18.00

MAIDENBLUSH, superb light pink; flowers well placed on tall, slender stem; extra florist variety and the easiest and earliest forcer, oftentimes producing two and three spikes to the bulb.............

MING TOY, showy deep buff with yellow throat; large flowers on tall, strong stem; very pleasing variety.

MYRA, deep salmon on yellow ground with faint pink lines in throat; very large flowers on long stem....

ORANGE QUEEN, purest apricot of a very warm tint; large, open flowers on good stem; justly considered one of the very choicest novelties in Prim. Hybrids.

ROSE LUISANTE, beautiful light pink, lower petals a shade lighter; magnificent flowerspike.........

SALMON BEAUTY, deep salmon with salmon-yellow throat; large, open flowers on tall, graceful spike..

SHELL PINK, rose pink with slightly mottled white throat; large flowers, well placed on tall, wiry stem.

$22.00 \quad 16.00$

13.00

$35.00 \quad 28.00$

22.00

$22.00 \quad 16.00$

13.00

$50.00 \quad 40.00$

32.00

$25.00 \quad 20.00$

16.00

$30.00 \quad 24.00$

18.00

$50.00 \quad 40.00$

32.00 


\section{PRIMULINES-.-Continued}

SOUVENIR, purest golden yellow of all Gladioli; large, beautifully shaped flowers on tall, slender stem....

TOPAZ, buff-orange, pure selfcolor of a very attractive, unusual shade; tall, graceful spikes; excellent forcer, blooming $150 \%$ or better................

PRIMULINES, mixed, a very fine mixture of all colors...

30.00

24.00

18.00

$20.00 \quad 16.00$

\section{ANEMONES}

Anemones can be planted outside any time in the spring. For greenhouse forcing plant during August in three-inch pots. Transplant in October in soil with perfect drainage, peat and sand mixed preferred. Space 8-10 inches both ways and water sparingly until the plants are up. Pinch out yellow and rotting foliage when growing. The small bulbs are better for forcing than the large bulbs.

Per 1000

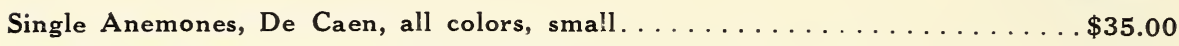

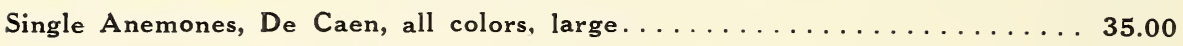

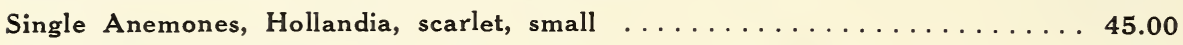

Single Anemones, Hollandia, scarlet, large $\ldots \ldots \ldots \ldots \ldots \ldots \ldots \ldots \ldots \ldots$

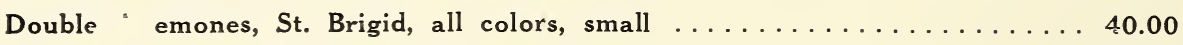

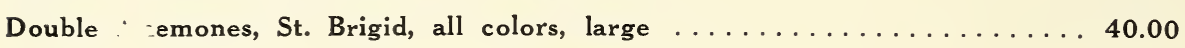

\section{BEGONIAS}

\section{(Tuberous rooted)}

January delivery. Flower in pots for Easter or later.

Single, in the following colors: pink, rose, orange, yellow, red, salmon, scarlet and white.
$1 \frac{1}{4}$-inch per $100, \$ 8.00$; per $1000, \$ 75.00$.
1 泡-inch per 100, $\$ 10.00$; per $1000, \$ 95.00$.
2 -inch per 100, \$12.50; per 1000, $\$ 120.00$.

Double, in the following colors: rose, pink, orange, yellow, red, salmon and scarlet.

$1 \frac{14}{4}$-inch per 100, $\$ 8.50$; per $1000, \$ 80.00$.

$11 / 2$-inch per $100, \$ 10.50$; per $1000, \$ 100.00$.

2 -inch per 100, \$13.00; per 1000, \$125.00.

\section{CANNAS}

At prices hereunder quoted we deliver strong, dormant 2-3 eyes divisions. Shipments November to April.

APRICOT, an entirely new color. A most pleasing mixture of buff and $\begin{array}{rr}\text { Per } & \text { Per } \\ 100 & 1000\end{array}$ salmon which gives the apricot shade, implied by its name. Of unusual merit and value. Grows four feet tall. Foliage bright

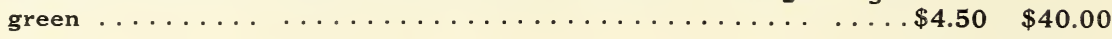




\section{CANNAS-Continued}

CHAS. HENDERSON, a free blooming variety of a scarlet crimson with rich yellow throat. Very large, compact trusses. Height $31 / 2$ to 4 feet. Green foliage................... 3.50

CITY OF PORTLAND, a well-known, very recommendable variety. Flowers are very large and of a beautiful shade of bright pink. Grows about $31 / 2$ feet tall. Foliage green..............

CRIMSON BEDDER, as the name indicates, a very popular variety for bedding. Color deep crimson red. Grows about $3 \frac{1}{2}$ feet tall.

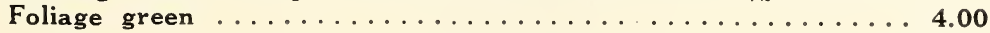

EUREKA, by far the best white Canna. Especially vigorous. Large flowers. A very free bloomer. Opens with a slight cream tint, but gradually becomes whiter. About 4 feet tall. Foliage bright green 5.50

FIRE BIRD, very large blossoms of a glossy, fiery red color. Strong stems which hold the flowers well above the foliage. About $31 / 2$ feet tall. Foliage bright green................5.00

FLORENCE VAUGHAN, a very strong growing kind. Flowers of the finest golden yellow shade. An old stand-by. Grows about 4 feet tall. Foliage green ................... 3.50

HUNGARIA, a dwarf canna. Color bright rose-pink, one of the most beautiful shades of pink to be found in any canna. Height from 3 to $3 \frac{1}{2}$ feet. Foliage green. Ideal for bedding...........

INDIANA, one of the best golden orange shades. Tall, erect stalks which keep the flowers well above the foliage. Grows about 6 feet tall. Foliage green ....................4.00

KING HUMBERT, enormous flowers of a flame scarlet, shading darker to the edges; 4 to 5 feet tall. Very large deep bronze leaves. Strong grower. Most popular variety..............4.00

MRS. ALFRED CONARD. It is hard to imagine a more gorgeous pink than this variety. It is a very robust plant with large flowers. Will stand the hottest sun. Grows to a height of about 4 feet. Foliage

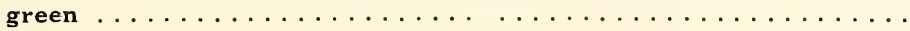

PRESIDENT. Flowers are of enormous size; rich scarlet color which will not bleach in the sun. Grows 4 feet tall; strong, erect stalks. Early bloomer. Foliage deep green. One of the best........4.50

RICHARD WALLACE. Very large flowers of a dainty canary-yellow. In a light yellow it is hard to find anything better. A very free bloomer, growing from 4 to $4 \frac{1}{2}$ feet. Foliage bright green... 4.00

STATUE OF LIBERTY. This is one of the giants among Cannas and everybody must admire its robust habits. Flowers of enormous size and uniformly colored brilliant red which shows some trace of dull orange. Large, slightly rounded foliage of a rich bronze color. Grows from 6 to 7 feet tall.................

WYOMING. An orchid flowering Canna producing enormous blossoms of deep orange. Strong, tall stems. Grows from 6 to 7 feet tall, and has luxuriant foliage of a deep bronze........... 3.50

YELLOW KING HUMBERT. A sport of the popular King Humbert, producing large flowers of the most beautiful shades of yellow, lightly spotted red. Four to 5 feet tall. Foliage dark green.... 4.50 


\title{
CALADIUM ESCULENTUM
}

\author{
(Elephant's Ear)
}

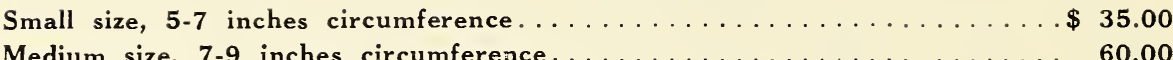
Large size, 9.11 inches circumference................. 110.00

\section{DAHLIAS}

Although our specialty is Gladioli, we have devoted a few acres to the best cutflower varieties in Dahlias. Prices are per 100 divisions of field-grown stock.

JEAN KERR (dec), pure white of fine form; a profuse bloomer on stiff stems; the best commercial white . . . . . . . . . . . . . . . . . $\$ 20.00$

JERSEY'S BEAUTY (dec), considered by all the best clear pink for all purposes 25.00

MAUDE ADAMS (show), blush white, tipped mauve pink; continuous and

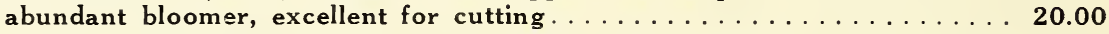

MRS. EDNA SPENCER (Hybr. Cact.), silvery lilac, shading to orchid pink;

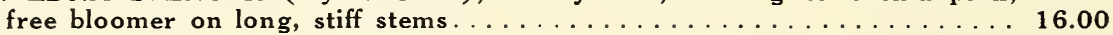

MRS. I. DE VER WARNER (dec), uniform, deep lavender pink; perfectly formed, large flowers on long, wiry stems; with Jersey's Beauty leading in the pinks this one leads in the lavender pinks. .

MRS. J. HARRISON DICK (dec), citron yellow at center, outer petals suffused and overlaid salmon pink, a lovely and effective combination. Wonderful grower, profusive bloomer, long stiff stems. Most valuable for cutting

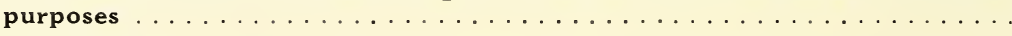

PATRICK O'MARA (dec), orange, suffused buff, a typical autumn color; its long stems and profuse blooming make it a desirable cutflower variety...

PRIDE OF CALIFORNIA (dec), deep red on stiff stems; especially suitable for warm climat

SOPHY MOREY (cactus), white, slightly suffused and overlaid phlox purple; delicately beautiful color; ideal in every way, large size, fine form, long stiff steins, a good keeper, vigorous grower and profuse bloomer.

SUNSET GLOW (Hybr. Cact.), yellow at base of petal, outer part overlaid flame scarlet, lightly tipped yellow. Early bloomer, perfect flowers, many blooms; one of the best for commercial purposes . . . . . . . . . . . . . . .

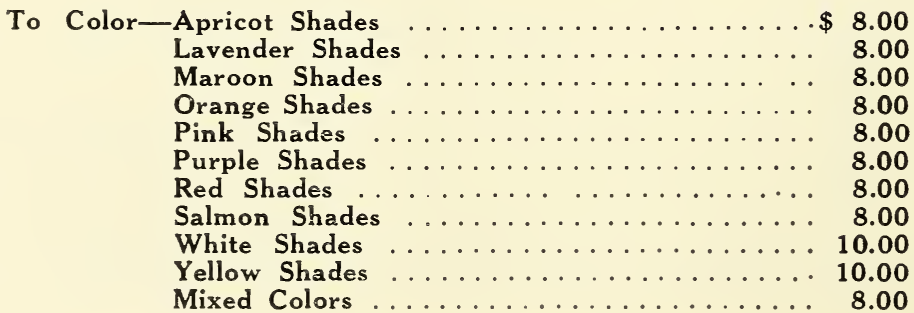




\section{PEONIES}

We are large growers of Peonies, 15 acres being devoted to these roots. Ask for our price list, which is ready in July.

\section{RENONCULES}

Mixed, all colors, per 1000 $\$ 40.00$

\section{SPIREAS}

(Astilbe)

Large, undivided, fieldgrown clumps.

\section{TRITOMA PFITZERI}

(Red Hot Poker)

\section{TUBEROSES}

\section{(Dwarf Pearl Excelsior)}

3 to 4 inches circumference. 



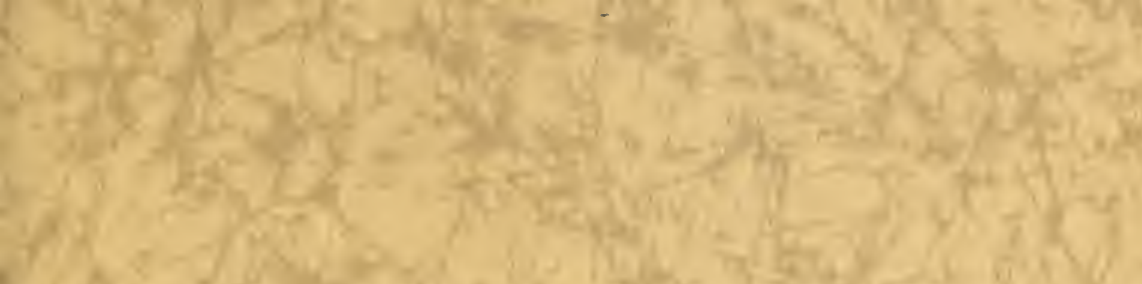

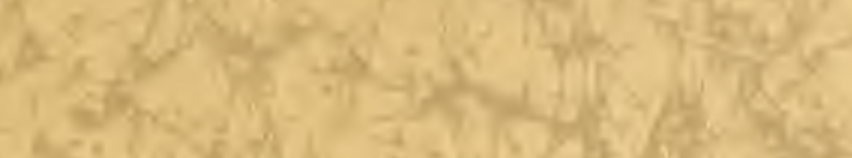

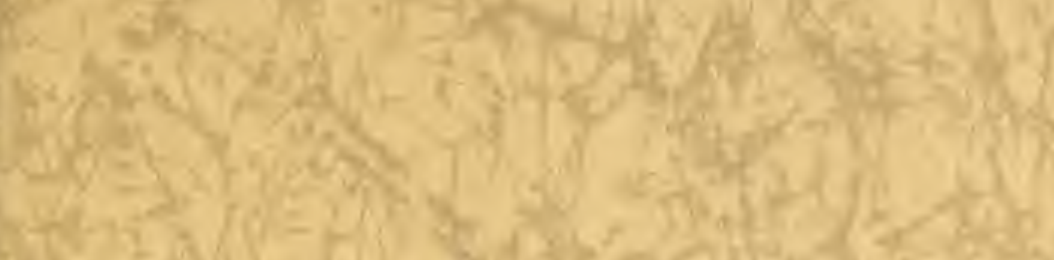

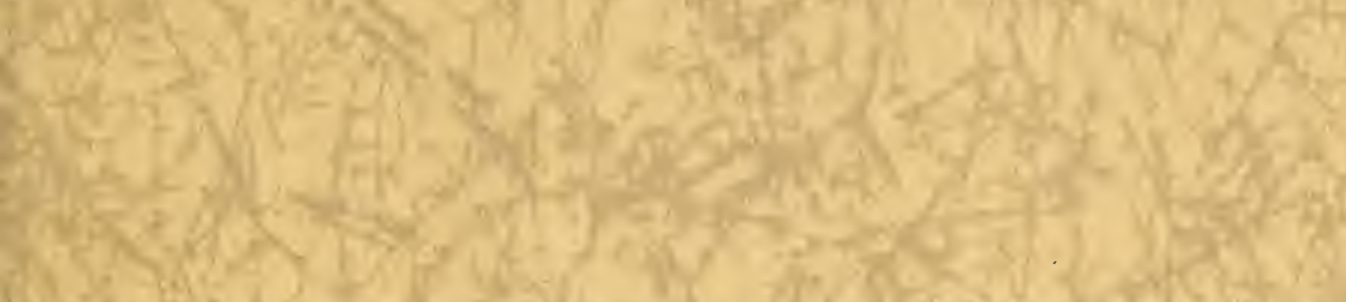

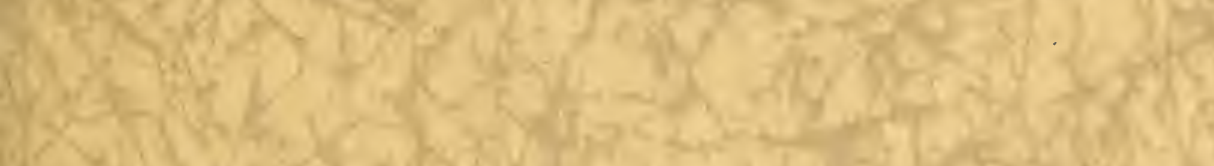

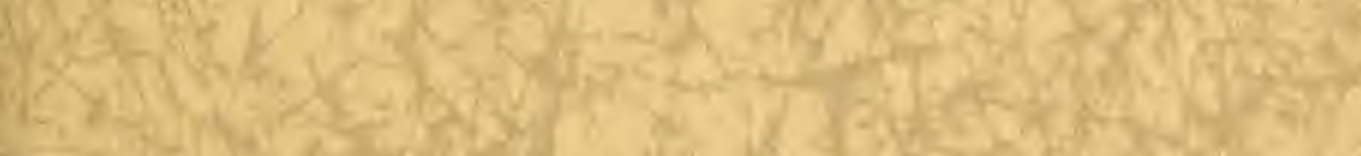

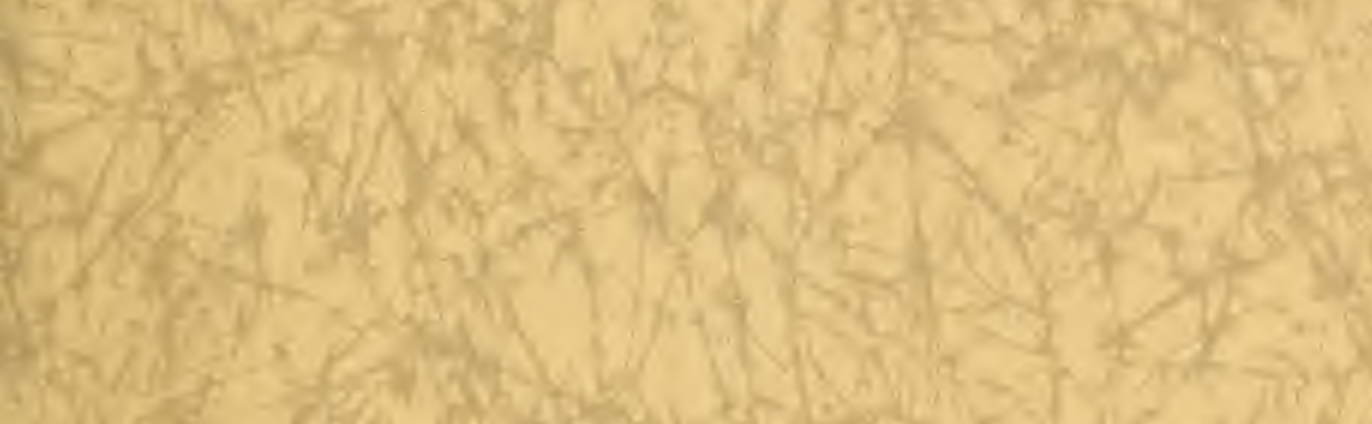

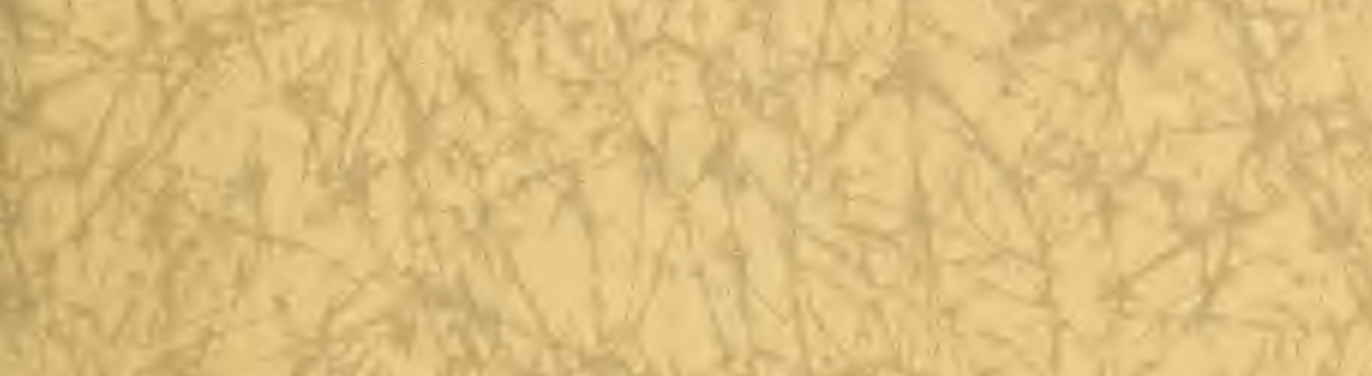

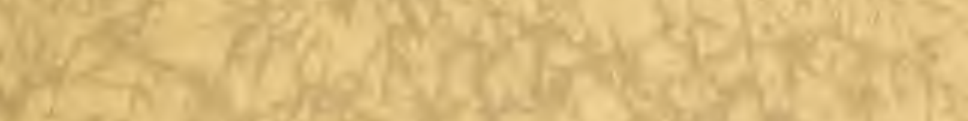

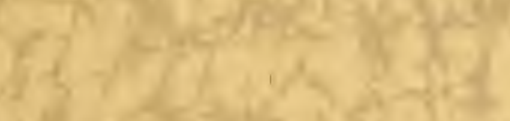

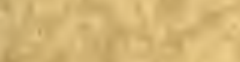

te

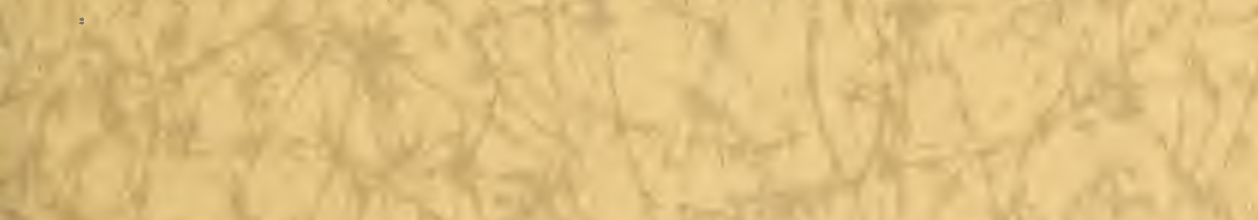<smiles>C1C2CC3C1C1CC2C31</smiles>

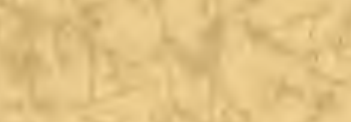

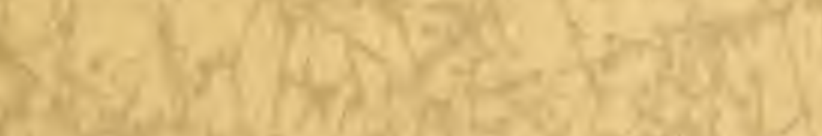

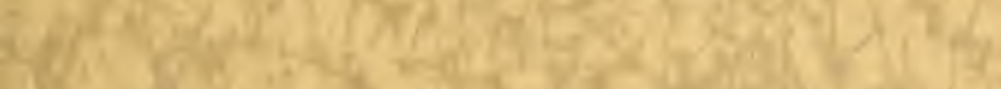

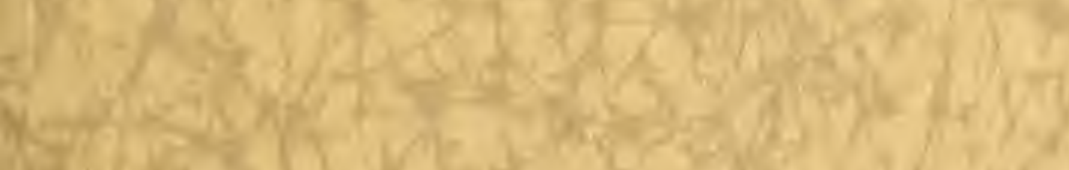

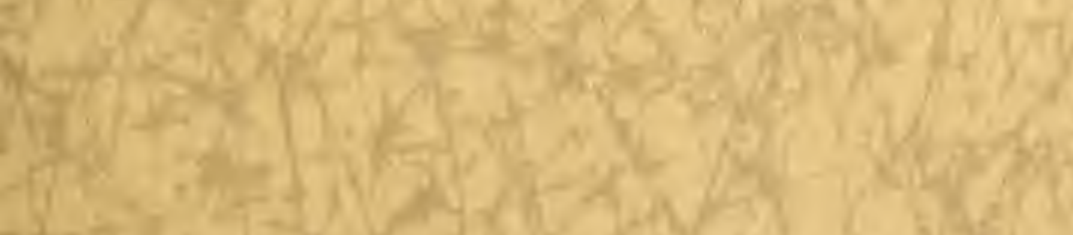




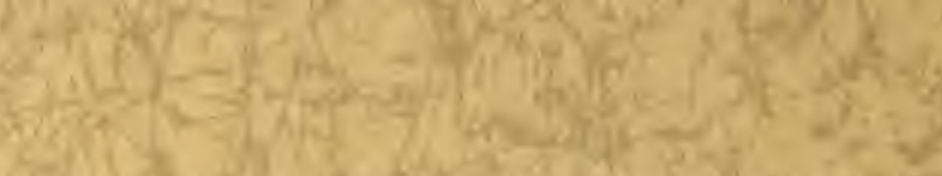

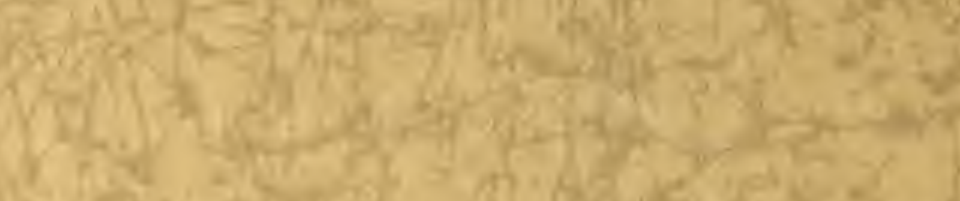

Misivisy

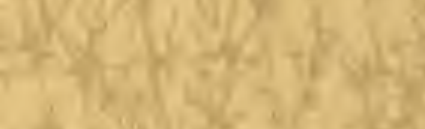

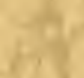

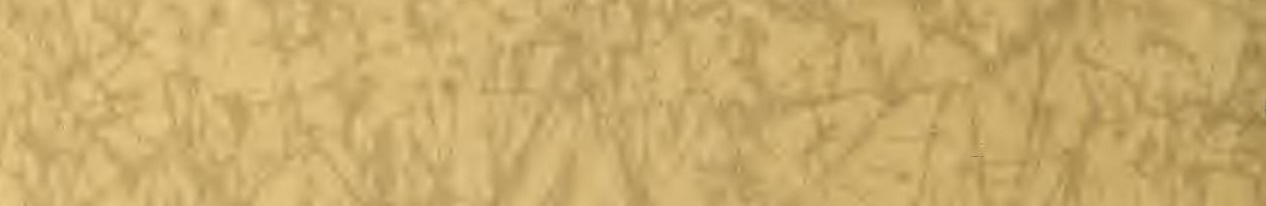

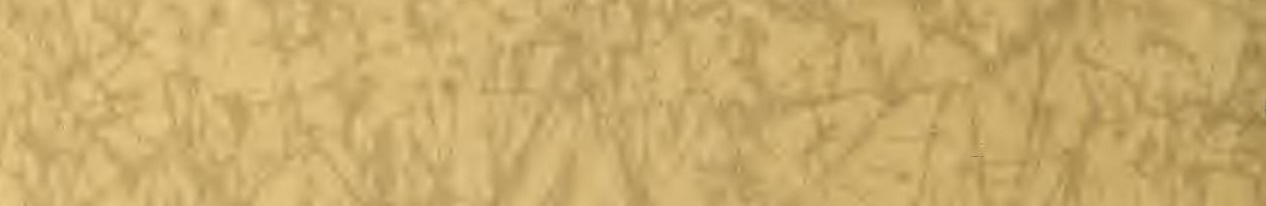
Ne

$2 \frac{1}{3}$

int

$+46 x^{2}$

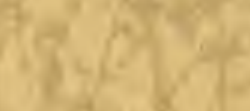

hases mistond

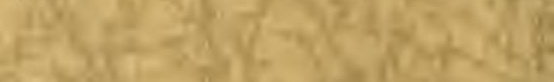

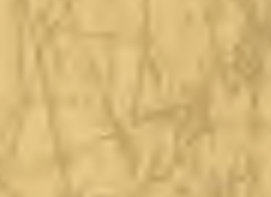

wats toys (8) m:

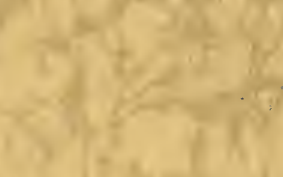

